\title{
CITIZEN SUIT ATTORNEY FEE SHIFTING AWARDS: A CRITICAL EXAMINATION OF GOVERNMENT-"SUBSIDIZED" LITIGATION*
}

\author{
BRUGE FEIN† \\ I \\ INTRODUCTION
}

\begin{abstract}
We think the District Court [in declining to award fees] incorrectly focused its attention on the outcome and practical effect of the litigation, to the exclusion of a more relevant consideration-whether the suit was the type that Congress intended to encourage when it enacted the citizen-suit provision .... The attorneys' fee feature was offered as an inducement to citizen suits, which Congress deemed necessary; and if the hope Congress had for such suits is to become a reality, decisions on fee-allowance cannot make wholesale substitutions of hindsight for the legitimate expectation of citizen plaintiffs. ${ }^{1}$
\end{abstract}

The court in Metropolitan Washington Coalition for Clean Air v. District of Columbia thus reasoned that the "public interest" aspect of a lawsuit filed to prevent air pollution was sufficient to justify an award of fees based on the attorney fee provision of the statute under which the suit had been brought, despite the fact that the plaintiffs did not prevail on the substantive issues in the case. ${ }^{2}$ Although the Supreme Court subsequently decided in Ruckelshaus $v$. Sierra Club ${ }^{3}$ that a court may not award fees when a plaintiff loses on all issues, ${ }^{4}$ the Court's rationale leaves little comfort for those who are justifiably concerned that decisions like Metropolitian Washington Coalition are examples of an endemic problem in recent federal legislation: permitting the federal judiciary to decide "policy" and to interfere in the daily operations of the executive branch. The Supreme Court's decision that the plaintiffs were precluded from recovering attorney fees because they did not prevail on any issue creates an insubstantial and ineffective obstacle to fee awards against the federal government.

Attorney fee shifting is the process of allocating the cost of services provided by attorneys among the parties to a lawsuit. Traditionally, parties pay their own

\footnotetext{
Copyright (c) 1984 by Law and Contemporary Problems

* The author gratefully wishes to acknowledge the assistance of those student editors of Law and Contemporary Problems who were responsible for much of the research and writing of this article.

$\dagger$ General Counsel, Federal Communications Commission. The views expressed in this article are the views of the author and do not necessarily represent the position of the Federal Communications Commission.

1. Metropolitan Washington Coalition for Clean Air v. District of Columbia, 639 F.2d 802, 804 (D.C. Cir. 1981).
2. Id.
3. 103 S. Ct. 3274 (1983).
4. Id. at 3281 . 
attorney fees in the United States. ${ }^{5}$ In the past twenty years, however, Congress has enacted numerous statutes which change the traditional approach by authorizing "citizen suits." Briefly stated, citizen suits are statutorily created causes of action brought by private individuals or groups, who need not have suffered personal harm, against federal agencies challenging the proposed or actual implementation of an administrative policy on the basis of its alleged inconsistency with authorizing legislation. These statutes all permit potential recovery of attorney fees and contain similarly phrased fee shifting provisions. ${ }^{6}$ The typical statutory provision provides that "[i]n any judicial proceeding under this section, the court may award costs of litigation (including reasonable attorney and expert witness fees) whenever it determines that such award is appropriate."7

These attorney fee shifting schemes, establishing a low threshold for a private party's entitlement to fees, have far-reaching consequences for our government and its efficient operation. This article does not analyze statutes that permit fee shifting in other actions against the government or among private parties. ${ }^{8}$ Accordingly, all types of civil rights actions, constitutional torts, and section 1927 awards of fees (awarded in cases of vexatious litigation and charged against the vexatious litigant's counsel) are not addressed. ${ }^{9}$ The limited inquiry chosen here is

5. Not long ago, the Supreme Court recognized that "[i]n the United States, the prevailing litigant is ordinarily not entitled to collect a reasonable attorney's fee from the loser." Alyeska Pipeline Serv. Cio. v. Wilderness Soc'y, 421 U.S. 240, 247 (1975). The origins of this rule precluding fee awards to the prevailing party lie in the common law. Id. See also Leubsdorf, Toward a History of the American Rule on Attorney Fee Recovery, LAw \& Contemp. Probs., Winter 1984, at 9.

6. Toxic Substances Control Act, 15 U.S.C. $§ 2618$ (d) (1982); Endangered Species Act, 16 U.S.C $\S 1540(\mathrm{~g})(4)$ (1982); Surface Mining Control and Reclamation Act, 30 U.S.C. $\$ 1270(d)$ (Supp. V 1981); Deep Seabed Hard Mineral Resources Act, 30 U.S.C. $\$ 1427$ (c) (Supp. V 1981); Clean Water Act, 33 U.S.C. § 1365(d) (1976); Marine Protection, Research and Sanctuaries Act, 33 U.S.C. § 1415(g)(4) (1976); Deepwater Port Act, 33 U.S.C. $§ 1515$ (d) (1976); Safe Drinking Water Act, 42 U.S.C. § 300j-8(d) (1976); Noise Control Act, 42 U.S.C. $\$ 4911$ (d) (1976); Energy Policy and Conservation Act, 42 U.S.C. $\$ 6305$ (d) (1976); Powerplant and Industrial Fuel Act, 42 U.S.C. $\$ 8435$ (d) (Supp. V 1981); Ocean Thermal Energy Conversion Act, 42 U.S.C. § 9124(d) (Supp. V 1981); Solid Waste Disposal Act, 42 U.S.C. § 6972(e) (1976); Clean Air Act, 42 U.S.C. $\$ 7607$ (f) (Supp. V 1981); Air Pollution Prevention Act, 42 U.S.C. $\$ 7622(\mathrm{e})(2)$ (Supp. V 1981); Energy Sources Development Act 42 U.S.C. $\$ 5851$ (e)(2) (Supp. V 1981); Outer Continental Shelf Lands Act, 43 U.S.C. § 1349(a)(5) (Supp. V 1981).

7. Clean Air Act, 42 U.S.C. $\$ 7607$ (f) (Supp. V 1981) (commonly referred to as section $307(f)$ ). The Supreme Court held in Ruckelshaus v. Sierra Club, 103 S. Ct. 3274 (1983), that the interpretation of section 307 (f) controls the construction of the sixteen other statutes cited in note 6 , supra. Id. at $3276 \mathrm{n} .1$.

8. This article will not examine, for example such fee shifting provisions as $\$ 304$ of the Clean Air Act, 42 U.S.C. $\$ 7604$ (d) (Supp. V 1981), which permits actions against private parties for violations of the Act and against the federal government for its failure to enforce existing regulations.

Other statutes that permit attorney fee shifting between private parties are also excluded from the analysis. See, e.g., Civil Rights Act of 1964, 42 U.S.C. $\$ 2000 a-3$ (1976) (permitting attorney fees to be awarded to successful plaintiffs). In total, there are more than 150 federal fee shifting provisions. Ruckelshaus v. Sierra Club, 103 S. Ct. 3274, 3276 (1983).

9. Whether a distinction should be drawn between citizen suit attorney fee shifting provisions and fee provisions in other statutory schemes is unclear. In Hensley v. Eckerhart, 103 S. Ct. 1933, 1937 (1983), the Supreme Court permitted an award of fees to a party that did not succeed on every claim under a standard which permitted fee awards only to prevailing parties. See also 42 U.S.C. $\S 1988$ (Supp. V 1981). The determination could be interpreted to mean that statutes permitting awards only to prevailing parties and statutes permitting awards when "appropriate," as in the case of citizen suits, are indistinguishable, especially in light of Ruckelshaus v. Sierra Club, 103 S. Ct. 3274 (1983). This conclusion does not, however, appear to be correct.

The Court in Ruckelshaus discussed the traditional American rule embodied in Alyeska Pipeline Serv. Co. v. Wilderness Soc'y, 421 U.S. 240 (1975), and then contrasted the operation of fee shifting schemes. 
for the purpose of uncovering the unique problems presented by fee shifting in citizen suits. The implications of attorney fee shifting provisions in citizen-suit legislation are far broader than the simple allocation of the costs of litigation. Citizen suits and their concomitant fee provisions empower the courts to decide the merits of challenges to administrative determinations and to award attorney fees and other litigation expenses when the circumstances are deemed "appropriate." When a court awards fees in a citizen suit, unlike other types of litigation, the impact of the award extends well beyond the parties to the case. Because potential citizen-suit plaintiffs ordinarily have not incurred any direct personal injury, the strongest incentive to sue is the attractive likelihood of recovering litigation expenses. As a result, awards in earlier citizen suits, through fee shifting precedent, often determine whether or to what extent subsequent suits will be initiated.

Citizen suits clog court dockets, slow the administrative process, shift policymaking to the judiciary, and undermine the very foundation of the American litigation scheme. ${ }^{10}$ These adverse consequences of citizen-suit attorney fee shifting necessarily debilitate the judicial system and blur the lines between the coordinate branches of government. More specifically, citizen-suit fee shifting obviously encourages people to sue the federal government because of the litigation incentive provided by the potential recovery of attorney fees and the lack of any major cost disincentive arising from such litigation because the fee shifting is effectively only one-way - from the government/defendant to the plaintiff." ${ }^{1}$ Because of frequent

Ruckelshaus, $103 \mathrm{~S}$. Ct. at $3276-77$ (1983). The Court then specifically described the operation of fee shifting in citizen suits: "[W]e believe that the term 'appropriate' modifies but does not completely reject the traditional rule that a fee claimant must 'prevail' before it may recover attorneys' fees." Id. at 3277. Despite the unfortunate word choice of "traditional" to describe other fee shifting schemes, given that the traditional rules do not permit fee shifting, the Court left open the possibility that different standards might apply to citizen suits and other statutes allowing fee shifting, regardless of the fact that Hensley could be interpreted otherwise.

10. The author's research has revealed no studies regarding what the specific effects of citizen suit legislation with generous fee shifting provisions are on the administrative process. But it is simply beyond dispute that the award of attorney fees to private litigants bringing citizen suits in the name of the public interest will drastically increase litigation against federal administrative agencies. Indeed, this is the declared congressional purpose behind these fee statutes. H.R. REP. No. 218, 95th Cong., 1st Sess. 88-89, reprinted in 1977 U.S. CODE CONG. \& AD. News 593, 626-27 [hereinafter cited as House Report]. It is also equally clear that as federal agencies become increasingly threatened by private citizen suits they will require greater study and reflection before taking any action that may produce such costly suits. The end result will be a collective regulatory reticence that seriously debilitates and slows the already delay-prone administrative process.

Equally significant, and no less distressing, is the obvious shifting of policymaking from agency experts to judicial dilettantes in the various areas of agency expertise. The numerous fee shifting provisions found in citizen-suit statutes uniformly grant the courts complete discretion to award litigation costs to citizensuit plaintiffs with only the amorphous notion of bad faith as their guide. Id. Liberal awards of fees will increase litigation and thwart agency action. Conservative fee awards will have the opposite result. In either event, the courts will be indirectly affecting, and in some cases determining, the course of agency action.

Finally, no rule is more deeply embedded in our jurisprudence than the principle that each party is responsible for its own attorney fees. See Alyeska, 421 U.S. at 247 . The rule is so fundamental that the judiciary cannot "jettison . . . [it] whenever the courts deem the public policy furthered by a particular statute important enough to warrant the [fee] award." Id. at 263. Citizen-suit fee shifting provisions are manifestly contrary to this paramount principle of litigation.

11. One reason that fees are shifted in only one direction is that Congress has not been clear as to the appropriateness of fee awards to the government. Although some of the seventeen statutes cited in note 6 , supra, use the language "to any party," none incorporates the language "including the Federal Govern- 
fee shifting, many plaintiffs' attorneys are likely to encourage citizen suit litigation beyond what is socially optimal in pursuit of government-provided attorney fees that may be obtained even when the citizen is not the prevailing party. ${ }^{12}$

The second fundamental problem of citizen suit fee shifting is that it substantially impedes the administrative process. Challenges to government policy, both a goal and a result of fee shifting legislation, ${ }^{13}$ delay the administrative process and reduce its efficiency. These challenges appreciably chill the administration of government by deterring administrators from experimenting with new ideas and innovative techniques. As the administrative process is slowed, the costs of implementation increase in real terms (at least in inflationary times) and substantial benefits are lost due to delay. Once lost, the benefits that would have resulted from an earlier implementation of the administrative action cannot be regained.

Finally, the lack of articulated legislative standards in citizen-suit statutes regarding the appropriateness of fee shifting tranfers policymaking from Congress to the courts. Although enabling legislation often delegates some discretion to administrative agencies (in general terms rather than delineating the particular areas in which citizen suits are available), such a legislative choice with respect to fee shifting leaves far too much policymaking discretion to the judiciary-the nonpolitical branch of government. Consequently, unelected and therefore politically unaccountable judges are required to make important policy choices regarding the appropriateness of fee shifting in each case and also to decide without invitation the validity of agency action or inaction at issue in citizen suits. Due to the generalized nature of harms alleged in citizen suits, and the concomitant drastic alteration in standing requirements, courts are increasingly required to give, in effect, advisory opinions because parties often intervene before any actual harm has occurred. Thus, the courts regularly make consequential policy decisions when the potential harm is purely speculative.

In an attampt to alleviate many of the troubling consequences flowing from

ment," a variation found in the Ship Pollution Prevention Act, 33 U.S.C. $\$ 1910$ (d) (Supp. V 1981). Notwithstanding that the Ship Pollution Act does not permit citizen suits, the premise for the provision in this Act is the same as that of the statutes permitting citizen suits: parties who come into court may be awarded their attorney fees. The general similarity of the language and legislative history of the Ship Pollution Act and citizen-suit statutes may lead courts to interpret the appropriateness of awards under any of these acts differently depending on slight differences in language. For an implicit suggestion that such similar language contained in different types of statutes will be analyzed comparatively, see United States v. M/V Zoe Colocotroni, 602 F.2d 12, 15 (1st Cir. 1979) (admiralty case). The First Circuit in $M / V$ Zoe discussed generally the appropriateness of fee awards to the federal government. The court stated: "Absent specific and express authorization by statute, the United States may not recover its [attorney] fees

"Id. The court in also discussed Save Our Sound Fisheries Ass'n v. Callaway, 429 F. Supp. 1136 (D.R.I. 1977), a citizen-suit case, which gave a narrow construction to who may recover attorney fees. Id. Thus, judicial interpretation supports the proposition that fee awards will be shifted only in one direction. Concededly it is not yet clear whether all courts adhere to this position; however, a review of the relevant reported authority does not reveal any cases in which fees were awarded to the government.

12. Attorney fee shifting leads to "mercenary attorneys"-lawyers who make a practice of handling suits with the potential for recovery of attorney fees. These attorneys encourage potential plaintiffs to pursue marginal claims which would otherwise remain unlitigated.

13. The accepted legislative purpose behind citizen suit fee shifting is "to encourage litigation which will assure proper implementation and administration" of the various remedial statutes under which attorney fee shifting is authorized to further the public interest. H.R. REP. No. 294, 95th Cong., 1st Sess. 337, reprinted in 1977 U.S. CODE CONG. \& AD. NEws 1077, 1416 [hereinafter cited as House Report]. 
attorney fee shifting legislation, this article suggests a model attorney fee statute. Assuming Congress is unwilling to abandon citizen suits, this model is a practical and moderate alternative to existing citizen suit legislation.

If citizen suits are to continue, they should be required to provide at least one articulable benefit to the public welfare. In the context of administrative agencies, the public interest is served by the disclosure of new information, the discovery of a previously unconsidered important interest, or the demonstration that a government agency has neglected to fulfill its nondiscretionary duties. Other challenges begin to enter the realm of properly delegated discretion and often are no more than another attempt to influence policy, this time, however, through the efforts of the judiciary which cannot and should not formulate regulatory policy. The model statute represents an attempt to further the above goals and is thus premised on the belief that citizen suits should provide a tangible benefit to the public good before the suing citizen is compensated. Although the statute is most appropriately included in the third section of this article on judicial policymaking, it serves as a helpful background when considering the impact of citizen suits on the courts and administrative agencies. Unfortunately, even this moderate approach cannot eliminate the inherent deficiencies of a system which relieves the litigant of the responsibility for the costs of his own litigation. With all this in mind, it is first necessary to examine closely the legislative purpose behind citizen suit-fee shifting. Without understanding the congressional reasons underlying established fee shifting provisions, it is impossible to analyze and weigh the benefits and costs inherent in the one-way fee shifting employed in citizen suits. Once the purpose of permitting fee shifting in citizen suits is clear, the deficiencies and disturbing consequences of relieving litigants of their attorney fees become manifest. It is clear that Congress correctly recognized that administrative agencies cannot be left completely unchecked and unwatched if agency regulation is always to further the public interest. Fee shifting is not, however, the proper remedy. Simply put, citizen-suit fee shifting against government regulatory agencies is a "solution" that is far worse than the problem it purportedly solves.

II

\section{Legislative History and Purpose}

With respect to citizen-suit attorney fee shifting, it has been observed that "[n]either legislative history nor case law offers interpretations of the statutory requirement that costs be granted only 'in an appropriate case." "' ertheless, some legislative history that ostensibly reveals the principal reasons for citizen-suit legislation and their concomitant attorney fee shifting provisions. In establishing citizen suits under the Surface Mining Act, ${ }^{15}$ Congress expressly recognized that

[ $t$ ] he success or failure of a national coal surface mining regulation program will depend, to a significant extent, on the role played by citizens in the regulatory process. . . . While

14. Carpenter v. Andrus, 499 F. Supp. 976, 978 (D. Del. 1980).

15. Surface Mining Control and Regulation Act, 30 U.S.C. $\S 1270$ (d) (Supp. V 1981). 
citizen participation is not, and cannot be, a substitute for governmental authority, citizen involvement in all phases of the regulatory scheme will help insure that the decisions and actions of the regulatory authority are grounded upon complete and full information. In addition, providing citizens access to administrative appellate procedures and the courts is a practical and legitimate method of assuring the regulatory authority's compliance with the requirements of the act. Thus in imposing several provisions [such as fee shifting] which contemplate active citizen involvement, the committee is carrying out its conviction that the participation of private citizens is a vital factor in the regulatory program as established by the act. ${ }^{16}$

Congress reasoned that because "citizens would be performing a public service" in bringing suits against administrative agencies, "the courts should award costs of litigation to such party." 17 Congress was not reluctant to transfer considerable regulatory policymaking discretion to the courts through citizen-suit legislation because it legislatively presumed without proof that the "[e]nforcement of . . . regulations is not a technical matter beyond the competence of the courts." 18 Nor was Congress concerned that fee shifting would increase the number of meritless claims brought against federal agencies. This lack of concern resulted from the Congressional assumption that "judges are quite capable of dismissing frivolous suits early in the proceedings." 19

On a more theoretical level, citizen-suit statutes were enacted by Congress to achieve a more desirable, efficient, and ultimately a more socially beneficial allocation of societal resources. Under statutes which concern the pollution of our environment and the conservation of our natural resources, for example, citizen suits have, without exception, been authorized. ${ }^{20}$ One reason for this is the economic character of pollution, which in a competitive market economy is known as an externality, a term generally defined as

a benefit or cost of a market transaction that is neither paid for nor received by those making the transaction, and therefore is not incorporated into the market demand or supply curve. If, for example, a manufacturing plant emits smoke that pollutes a town and causes its citizens to get lung cancer, there is a social cost of the operations of the firm that will not be felt by the firm and will not influence its price or quantity supplied. ${ }^{21}$

Externalities are market imperfections that can be justifiably remedied through government intervention. ${ }^{22}$ That is why Congress has enacted so many antipollution and conservation statutes. These statutes attempt to achieve the socially optimum allocation of resources by weighing the quantifiable economic benefits of pollution-producing activities against the damage to human health and the environment caused by pollution and excessive resource exploitation.

To administer and enforce these remedial statutes, Congress has created numerous federal regulatory agencies. Citizen-suit statutes and their attorney fee shifting provisions represent an implicit congressional recognition that these agencies are not immune from error or bias. Under these statutes, rather than relying

16. House Report, supra note 10, at 625.

17. 1972 U.S. CODE CONG. \& AD. News 3744,3747

18. Id.

19. House Report, supra note 10, at 627.

20. See, e.g., statutes cited supra note 6.

21. E. Gramlich, Benefit-Cost analysis of Government Programs 19 (1981).

22. Id. 
on federal attorneys general, an unbiased watchdog committee, or some other mechanism of ensuring the appropriateness of agency action, Congress has provided that citizens become "private attorneys general" and "agency watchdogs."23 It is thus clear that Congress had legitimate economic concerns in mind when it enacted citizen-suit fee shifting provisions. The more difficult question, however, is whether fee shifting is a desirable and appropriate mechanism to control agency regulation and thereby to help to achieve the substantive policy goals under the major antipollution and conservation statutes. ${ }^{24}$

III

\section{Critizing Citizen-Suit Attorney Fee Shifting}

\section{A. Litigious Litigants}

The American tradition of litigation dictates that each party should bear its own litigation costs, including attorney fees. ${ }^{25}$ Consequently, in the absence of specific statutory authorization, contract, or extraordinary circumstances, the "American rule" requires that a party pay his own attorney fees, even if he prevails. ${ }^{26}$ The traditional approach requires that a party considering litigation evaluate the risk of unsuccessful litigation and estimate the costs associated with it when computing the net benefit of further pursuing its claim. This salutary cost/benefit analysis by potential litigants helps prevent improvident, unnecessary, and often costly litigation. It also greatly reduces the pursuit of unfounded or frivolous claims.

Accepting the existence of some fee shifting, an alternative more acceptable than the one way shifts of the current citizen suit scheme is two-way fee shifting. This is an option which the system under consideration manifestly ignores. Under the present fee shifting system, when fees are awarded they are given almost invariably to the private litigant. The courts have indicated that the government is entitled to receive its litigation costs only if a private plaintiff brings a completely frivolous suit. ${ }^{27}$ Thus, the courts exacerbate, rather than ameliorate, the inherent deficiencies of fee shifting, encouraging parties plaintiff to litigate by presenting the appealing prospect of receiving a fee award, and the highly unlikely possibility of a penalty in the form of fees assessed. ${ }^{28}$

23. Carpenter v. Andrus, 499 F. Supp. 976,979 (D. Del. 1980).

24. Of course, this question necessarily subsumes the proposition that attorney fee shifting may in some circumstances be an appropriate mechanism to accomplish substantive policy goals. Although the author is unwilling to accept this questionable proposition, extended discussion of this far more philosophically perplexing question must be left to another article.

25. See supra note 5 and accompanying text.

26. Id.

27. See Christiansburg Garment Co. v. EEOC, 434 U.S. 410, 421 (1978) (fees awarded, in the court's discretion, to defendant in civil rights action, if plaintiffs action was frivolous, vexatious, or brought in bad faith); see also supra note 8 . Courts discuss the premise of fee shifting as encouraging private parties to enforce provisions of federal acts and moving the government towards one goal or another. See, e.g., Save Our Sound Fisheries Ass'n v. Callaway, 429 F. Supp. 1136, 1139 (D.R.I. 1977) ("The possibility of such fees serves as an incentive for private parties to enforce provisions of various statutes deemed too important to be left to the limited enforcement resources of the Justice Department.").

28. The House Committee on Interstate and Foreign Commerce intended that the statute permit the 
An additional problem of fee shifting arises when certain beneficiaries of the citizen suits employ them for personal gain. Because fees are not awarded on the basis of the ability to pay, ${ }^{29}$ wealthy plaintiffs and plaintiffs with a pecuniary interest in the outcome ${ }^{30}$ may file a citizen suit even though they could otherwise easily afford to undertake such litigation. These wealthy plaintiffs, often environmental or other interest groups advocating their position on an issue, are able to increase immensely the amount of litigation they undertake because the government effectively "subsidizes" their suits.

Attorney fee shifting in citizen suits encourages individuals or groups with nearly frivolous or only marginally colorable claims to challenge the implementation of government policies in court. Unfortunately, the Supreme Court in Ruckelshaus $v$. Sierra Club ${ }^{31}$ precluded an award of attorney fees to plaintiffs only when they fail to prevail on any issue: "[w]e hold that, absent some degree of success on the merits by the claimant, it is not 'appropriate' for a federal court to award attorneys fees . . . ."32 Thus, the possibility remains that a party might be successful on only one claim among many and still recover attorney fees. ${ }^{33}$ The primary consequence of this rule is that the award of attorney fees may turn solely on the skill of counsel, thereby favoring those plaintiffs whose attorneys are able to win on a relatively unimportant subsidiary issue, even though failing on the merits of the case as a whole. Once the plaintiff prevails on a single issue, it may be argued that the interests brought out in the course of litigation exemplify the type of citizen participation Congress intended to encourage and reward when it established fee shifting. ${ }^{34}$

Unlike the American rule, the current citizen-suit attorney fee structure provides potential plaintiffs few disincentives to litigate. The prospect that plaintiffs will have to pay attorney fees is so remote that few parties would even briefly consider it. To the extent that these suits are litigated in the "public interest," it appears that a court will be reluctant to assess fees against a plaintiff without specific congressional direction. The end result is the troublesome "floodgates"

award of attorney fees even when the plaintiff was not the prevailing party. House Report, supra note 13 , at 1416. See also Save Our Sound Fisheries Ass'n v. Callaway, 429 F. Supp. 1136, 1145 (D.R.I. 1977) (the awarding of fees to plaintiffs who prevail in citizen suits is the general rule and not the exception).

29. The economic position of plaintiffs is considered irrelevant with respect to the award of attorney fees under citizen suits. Save Our Sound Fisheries Ass'n v. Callaway, 429 F. Supp. 1136, 1146 n. 15 (D. R.I 1977). To be sure, "[t]here is no indication that Congress meant to limit . . . [awards of attorney fees] to public interest groups nor is there any basis for disqualifying a party from receiving an award merely because that party is solvent and has a financial interest in the outcome of the litigation." Florida Power \& Light Co. v. Costle, 683 F.2d 941, 943 (5th Cir. 1982) (citation omitted).

30. Florida Power \& Light Co. v. Costle, 683 F.2d 941, 943 (5th Cir. 1982).

31. 103 S. Ct. 3274 (1983).

32. Id. at 3281 (emphasis added).

33. For a discussion of the appropriateness of awarding fees to "partially prevailing parties," see id. at 3279 .

34. See, e.g., Village of Kaktovik v. Watt, 689 F.2d 222, 224 (D.C. Cir. 1982) (plaintiffs lost on all issues and fees were not awarded, but total loss on issues presented not considered determinative regarding the fee award); Northern Plains Resource Council v. EPA, 670 F.2d 847, 848 (9th Cir. 1982). Surprisingly enough, the plaintiff need not prevail on any issue so long as "the case presented novel, complex, and manifestly unclear questions concerning the interrelationships" between the governing Acts. North Slope Borough v. Andrus, 507 F. Supp. 106, 108 (D.D.C. 1981). 
problem - a host of suits filed to challenge administrative rulings because of the "no-lose" proposition presented to plaintiffs under citizen-suit statutes. The problem is currently most acute in the environmental area because legislation on this subject has been a focal point of activist groups during the Reagan Administration. The environmental situation highlights the fact that groups no longer in power, in this case the environmentalists, are likely to challenge government action in the courts where their present political powerlessness does not prevent them from pursuing and perhaps achieving their policy objectives. The prospect of recovering attorney fees further encourages these groups to resort to the courts.

The short-circuiting of the administrative process resulting from court challenges to duly enacted administrative schemes is explored in more depth in the next section. For now, suffice it to say that such activities by groups out of power represent a clear circumvention of the political decisionmaking process. It is disturbing to realize that wealthy special interest groups often use the courts as a vehicle to evade the political process altogether by continually challenging administrative determinations under citizen-suit legislation. In addition, by encouraging lawsuits the entire process threatens to overwhelm already overcrowded court dockets. ${ }^{35}$ The likelihood of increased litigation grows as administrations more closely aligned with one end or the other of the political spectrum are elected. Even though not all citizen suits are brought because of statutory fee shifting provisions, the existence of such provisions only encourages, as intended by the legislative drafters ${ }^{36}$ the filing of such lawsuits. In authorizing citizen suits, Congress either ignored or simply failed to recognize the serious consequences of citizen-suit legislation for the courts, the administrative process, and society as a whole.

\section{B. Unadministrable Administrative Agencies}

The legislative branch legislates and the executive branch implements. This unsophisticated axiom of our government is common knowledge. But since the early days of our Republic a profound change has occurred inasmuch as executive branch action, through its administrative agencies, effectively "legislates" in many areas in which Congress chooses to grant agencies broad authority without specific standards for its use. Administrative rulemaking has evolved to approximate many of the functions of Congress. More recently, a new twist to an old story is evident in the form of citizen-suit statutes in which Congress, by encouraging such suits through pro-plaintiff fee shifting, effectively leaves to the courts the task of implementing congressional policy.

This recent shift in the responsibility for implementing congressional policy threatens the administrative process with the impairment of experimentation and

35. The following examples of attempts to expedite court dockets reflect a growing concern that courts are backlogged. E.g., 2D CIR. R. 34(g) note (determination by court not to hear oral argument); 4TH CIR. R. 7(b) (disposition of appeal without oral argument), 18 (unpublished opinions). See also Nesnite, Managerial Judges, 96 HARv. L. REv. 361 (1982); Remarks of Justice Lewis F. Powell, Jr., ABA Division of Judicial Administration, San Francisco (August 9, 1982).

36. See, e.g., Save Our Sound Fisheries Ass'n v. Callaway, 429 F. Supp. 1136, 1139 (D.R.I. 1977). 
the prospect of substantial delay insofar as any individual may file suit to challenge an agency decision. ${ }^{37}$ The administrative agencies, which are the subject of the seventeen statutes cited at the beginning of this article, ${ }^{38}$ face a number of formidable tasks in implementing the directives of Congress. The agencies must not only interpret legislative intent, but also consider a number of special interests, including industrial and environmental lobbies which attempt to persuade the agency that their interpretation is closest to the actual intent of Congress. An example helps to illustrate the tremendous difficulty encountered by federal agencies in carrying out the legislative commands of the various antipollution and conservation statutes under which citizen-suit fee shifting is typically permitted. The 1977 Clean Air Amendments required the Administrator of the Environmental Protection Agency (EPA) to promulgate

$[N]$ ot later than one year after the enactment of the Clean Air Amendments . . . a national primary ambient air quality standard for $\mathrm{NO}_{2}$ concentrations over a period of not more than 3 hours unless, based on the criteria issued under section 108(c) [42 U.S.C. $\S 7408$ (c)] he finds that there is no significant evidence that such a standard for such a period is requisite to protect public health." 39

The broad discretion granted the Administrator of the EPA enables him to balance a variety of interests, reach a workable solution to a complex problem, and yet remain within the specific bounds of the applicable enabling legislation. Congress purposely left to the discretion of the Administrator the task of interpreting the congressional mandate because of his perceived experience and expertise. Citizen suits can easily distort this mandate by providing an opportunity for judicial interference where such meddlesomeness is unlikely to result in a solution appreciably better than its administrative predecessor. ${ }^{40}$

A subsidiary, but equally important, result of statutes that authorize citizen interference in the administration of government is the chilling of administrative agency experimentation. As the Supreme Court noted long ago, the science of government is the science of experiment. ${ }^{41}$ Congress wisely leaves substantial discretion with the agencies to permit and encourage the fashioning of programs and remedies which effectuate legislative purposes, while taking into account the practical implications and costs of alternative methods. ${ }^{42}$ One example of this flexibility is the EPA's "bubble concept" for air pollution emissions control. This

37. See, e.g., Village of Kaktovik v. Watt, 689 F.2d 222, 226 (D.C. Cir. 1982) (costly six month delay in leasing of land to develop energy resources was not justified by the apparent insignificance of alleged public benefits from citizen suit challenge); Colorado Public Interest Research Group, Inc. v. Train, 373 F. Supp. 991, 995 (D. Cal. 1974) (exacerbation of energy crisis due to economic impact and delays caused by energy plant shutdown not justified by potential benefits of citizen-suit challenge)

38. See supra note 6.

39. 42 U.S.C. $\$ 7409$ (c) (1982). The implementation of this standard could have been challenged under section 307(f) of the Clean Air Act, one of the seventeen statutes that are the focus of this article.

40. A wealth of literature exists criticizing the inability of courts to understand and competently analyze complex technical matters on a regular basis. See, e.g., Ethyl Corp. v. EPA, 541 F.2d 1, 67 (D.C. Cir.), cert. denied, 426 U.S. 941 (1976) (comments of Judge Bazelon on the danger of having scientific data reviewed by "technically illiterate judges").

41. Anderson v. Dunn, 19 U.S. (6 Wheat.) 209, 226 (1821)

42. See, e.g., Village of Kaktovik v. Watt, 689 F.2d 222, 225 (D.C. Cir. 1982) (one purpose of the statute was to expedite development of energy resources). See also Watt v. Energy Action Educ. Found., 454 U.S. 15l, 154 (1981) (Secretary of Interior given discretion to try experimental bidding systems for offshore oil leases). 
policy alternative balances increases in emissions from new or modified equipment with corresponding decreases in emissions from other equipment at the same plant so long as the total emissions from the plant remain within specified levels. ${ }^{43}$ Permitting citizen suits where the complexity of a problem requires unencumbered experimentation tends to discourage agencies from taking new approaches such as the bubble concept, which although unconventional may best achieve the long term objectives of Congress. The present system far too easily permits adjudicative attacks on this experimentation, leading to the almost certain prospect that agencies will simply take the path of least resistance to avoid judicial admonition. ${ }^{44}$

Conflict between agency enabling legislation and suit provisions creates an uncertainty regarding the proper role of citizen suits. There is no guarantee that the interests of an individual in bringing a citizen suit will be any more consonant with the policy underlying agency enabling legislation than those of many large corporations which are most often the object of antipollution and conservation regulation. It may be cogently argued that citizen suits were only intended for extreme circumstances. These rare and extraordinary circumstances would generally be limited to cases in which an administrative agency significantly and inexplicably deviated from its congressional mandate. Otherwise, citizen suits could be constantly used to impede the daily operations of administrative agencies, causing additional costs borne by the public. Surely this could not have been the intention of Congress when it enacted the citizen-suit provisions. Village of Kaktovik v. Watt ${ }^{45}$ provides an example of litigation which added little substance to the interpretation or implementation of the underlying statute and was extremely costly with respect to general litigation expenses, lost licensing fees, and delay to the government. ${ }^{46}$ Even though the court in Kaktovik found that the litigation created an "adverse impact on our national security and economy," 47 the court declared that the citizen-suit provisions required the award of attorney fees to the plaintiffs if they prevailed on any issue. ${ }^{48}$ An interpretation of citizen-suit provisions which limits litigation to cases of outrageous abuses of administrative authority would strike a more desirable balance between effective administrative decisionmaking and purposeful citizen participation.

While it is conceded that the administrative system contemplates a certain amount of judicial oversight of agency actions, the substantial increase in judicial oversight created by the existing citizen-suit statutes and their corresponding fee shifting provisions weakens the entire administrative process. As agencies concern

43. See 41 Fed. Reg. 16,280 (1981).

44. See Panel IV-Judicial Review of Agency Action, 26 AD. L. REV. 545, 553 (1974), remarks of Kenneth Cox, Institute of Federal Agencies and the Public Interest, ABA Section of Administrative Law (proposition that agencies become more cautious contributing to a variety of problems including increased delay).

45. 689 F.2d 222 (D.C. Cir. 1982).

46. The government determined, for example, that the cost of delay in Kaktovik was at least $\$ 15$ million in lost interest on lease payments delayed. Id. at 226. For analogous examples in the area of private-party litigation, see J. Lieber man, The Litigious Society 96 (1981); Porter, The Need for Finality On the Administrative Process: Problems in Licensing Nuclear Power Facilities, 17 Wake Forest L. REV. 25, 110 (1981)

47. 689 F.2d at 226 (D.C. Cir. 1982).

48. Id. 
themselves with looking over their shoulders to see how judges will act, agency authority will be unavoidably diminished because their decisions will have no sense of finality. In turn, judges will be forced to assert authority in fields in which they have little or no expertise, education, and experience. ${ }^{49}$ Judges must not only ensure that the requisite procedures have been followed-a traditional judicial role-but also interpret the applicable substantive law and thereby displace the primary function of the agencies. Accordingly, the administrative responsibility shifts to these inexperienced judges who must decipher what Congress meant in a political and technical sense by a given statutory scheme in the context of a specific set of adjudicative facts.

Increased judicial oversight has been fueled by the fee shifting provisions of citizen-suit legislation. Parties are encouraged, indeed actually "paid," to come into court and upset the administrative machinery because the possibility of a penalty (in fees assessed) is effectively nonexistent, whereas the probability that the government will involuntarily finance the lawsuit is extremely high so long as the litigation is perceived as a "public benefit" of implementation or interpretation. ${ }^{50}$ Unknowledgeable judges will have unlimited opportunities to impede the implementation of salutary administrative policies and procedures, resulting in unnecessary delay, ${ }^{51}$ enormous costs, ${ }^{52}$ and administrative agency atrophy. ${ }^{53}$

\section{Economic Inefficiency Under Citizen Suit Attorney Fee Shifting}

The application of basic economic theory to citizen-suit attorney fee shifting reveals that such a statutory departure from the American rule for the payment of attorney fees inevitably results in an inefficient allocation of societal resources. In seeking to remedy the problems of agency error and bias, Congress has created a "solution" in the form of citizen suit fee shifting that is more harmful than the problems it attempts to eliminate. Citizen-suit fee shifting represents no more than another instance of congressional overcorrection. Upon close inspection, it appears that a legislative gash was made by Congress where only a delicately executed surgeon's incision was needed.

An economic analysis of citizen-suit fee shifting must begin with a review of general microeconomic principles. First, the government must require pollution

49. See, e.g., Industrial Union Dep't v. American Petroleum Inst., 448 U.S. 607 (1980) (benzene exposure standards); United Steelworkers v. Marshall, 647 F.2d 1189 (D.C. Cir. 1980) (OSHA lead exposure standards); Alabama Power Co. v. Costle, 606 F.2d 1068 (D.C. Cir. 1979) (Clean Air Act standards); BASF Wyandotte v. Costle, 598 F.2d 637 (1st Cir. 1979) (Federal Water Pollution Control Act).

50. Florida Power \& Light v. Costle, 683 F.2d 941, 943 (5th Cir. 1982).

51. See, e.g., Village of Kaktovik v. Watt, 689 F.2d 222, 226 (D.C. Cir. 1982) (unsuccessful citizen-suit challenge resulted in a six-month delay in the lease sale of the Alaska Continental Shelf); see also Note, The Judicial Role In Defining Procedural Requirements for Agency Rulemaking, 87 HARV. L. REV. 784, 785 (1974).

52. See, e.g., Village of Kaktovik v. Watt, 689 F.2d 222, 226 (D.C. Cir. 1982), where the government estimated that the six-month delay caused by an unsuccessful citizen-suit challenge to its proposed lease of the Alaska Continental Shelf resulted in direct costs to the government in excess of $\$ 15,000,000$ and indirect ripple effect costs to the economy as a whole approaching $\$ 60,000,000$.

53. On the consequences of judicial excess, Chief Justice Burger has warned that "[w]hen the political institutions are not forced to exercise constitutionally allocated powers and responsibilities, those powers, like muscles, tend to atrophy." Plyler v. Doe, 457 U.S. 202, 253 (1982) (dissenting opinion); see also A. Bickel, The Least Dangerous Branch 21 (1962) 
producing firms to pay for the costs of their harm to the environment to achieve a socially optimum allocation of resources. ${ }^{54}$ Although the collective cost to society of pollution is high, the cost of pollution borne by each individual is not sufficient to induce individual action against polluters. Second, it is axiomatic that in a market economy individuals act to further their own personal pecuniary interests. ${ }^{55}$ Finally, it should not be overlooked that "the governmental administrative machine is not itself costless," 56 and that despite good intentions "direct governmental regulation will not necessarily give better results than leaving the problem to be solved by the market or the firm." 57

Litigation is not a costless activity. Thus, a party will pursue litigation in the absence of subsidy (the American rule) only when the perceived benefits exceed the predicted costs and associated risk attendant to a particular claim. Citizen-suit fee shifting effectively makes private actions against federal agencies costless except on those rare occasions when the courts refuse to award fees because the public benefit was not in any way furthered by the lawsuit. Fee shifting removes the most substantial constraint on litigation-attorney fees. The inescapable result is a costly and unrestrained growth in litigation against federal agencies. It is quite easy, no doubt, to conceive of hypothetical situations in which an absurd award of fees might be made because the public interest was marginally benefited, despite the enormous direct and consequential costs of the litigation. One need not, however, resort to legal imagination to find such instances. In Village of Kaktovik $v$. Watt, ${ }^{58}$ for example, the concern of various environmentalists over the possible adverse impact on whales from the sale of the Alaska Continental Shelf delayed the sale for six months. The cost of this delay was estimated to exceed $\$ 75,000,000 .{ }^{59}$ Although the court refused to award fees to the plaintiffs, such an award was sought and apparently expected. ${ }^{60}$ The prospect of an award of attorney fees provided by the applicable citizen suit fee shifting provision was a substantial, if not an overriding, inducement to the plaintiffs in Kaktovik to bring suit against the government. In causation terms, "but for" the propsect of attorney fees the plaintiffs in Kaktovik probably would not have brought suit. Few individuals except the most ardent of whale lovers would seriously contend that the Kaktovik citizen suit was an appropriate, desirable, or efficient allocation of societal resources. Even fewer individuals would argue that an award of attorney fees in

54. One economist has explained that pollution requires government intervention to achieve market efficiency

[b]ecause important environmental costs are not covered in the resource-use charges, [and therefore] the market economy's adjustment, in terms of both least firm cost and broader 'public interest' objectives, falls short of the ideal . . . . If there were a price penalty for polluting, the costs of abatement would be imposed upon the production process and adjustments would be made in resource use.

L. Hines, Environmental Issues 226 (1973). See also E. Gramlich, supra note 21, at 19-20.

55. A. Smith, The Wealth of Nations 345 (London, 1893).

56. Coase, The Problem of Social Cost, in Microeconomics, Selected Readings 368 (E. Mansfield ed. 1971).

57. Id.

58. 689 F.2d 222 (D.C. Cir. 1982).

59. Id. at 226 .

60 . Id. at 228 . 
Kaktovik was justified regardless of whether the plaintiffs in that suit prevailed on any issue, especially if they failed to prevail on the predominant issue in the case.

There remains a second major economic criticism of citizen-suit fee shifting that cannot be ignored. Congress mistakenly presumed that private citizens will always or usually base the decision to bring a citizen suit on whether the public interest is thereby furthered. Such economic altruism is unlikely to be found in the typical citizen-suit plaintiff. For it is no less true now than it was over two hundred years ago that, as the great market economist Adam Smith then declared, "every individual . . . neither intends to promote the public interest, nor knows how much he is promoting it. . . . [H]e intends only his own gain."61 Concededly, the public interest and the interest of the citizen-suit plaintiff may occasionally be coextensive, but this relationship is more likely a product of chance than necessity. The result of a national referendum regarding the decision to bring a particular citizen suit would probably, more often than not, differ from the decision made by an individual or interest group minority. But because of the likelihood of an award of fees these individuals will bring citizen suits irrespective of whether the public interest is actually and substantially furthered. ${ }^{62}$

Fundamentally, citizen-suit fee shifting is economically unsound. Routine fee awards lead to an excessive amount of litigation against federal agencies. And the private interests of individual citizen-suit plaintiffs have no necessary or demonstrated nexus with the public interest.

\section{Judicial Policymaking}

1. The Ubiquitous Judiciary. Citizen-suit statutes and their associated fee shifting provisions remove the principal disincentives to suits against federal agencies and thus impede the administration of government. ${ }^{63}$ Although direct, these consequences may not, however, be the most deleterious. ${ }^{64}$ Ultimately, citizen-suit statutes authorizing attorney fee awards that provide litigation incentives shift policymaking from the legislative and executive brances of government to the unelected and politically unaccountable judicial branch. These statutes accomplish this shift by relaxing historically self-imposed prudential limitations on the federal judiciary, by leaving crucial statutory terms undefined, and by failing to provide the courts with standards they can apply. Such a transfer of policymaking from the legislature to the judiciary "raises the justifiable concern that important

61. A. SMITH, supra note 55, at 345. Admittedly, Adam Smith meant by this remark that the each individual acting in pursuit of his own personal gain would, through the "invisible hand" of the market, further the public interest by assisting society in reaching an efficient allocation of resources. Id. But the market situation of which Adam Smith so eloquently spoke has been destroyed by citizen-suit fee shifting legislation. The market for litigation exists only where the American rule prevails. Fee shifting destroys this natural market by removing the cost-of-litigation restraint for one party.

62. In determining whether to award fees to a citizen-suit plaintiff the courts have articulated the requirement that the suit further the public interest in some way. Carpenter v. Andrus, 499 F. Supp. 976 , 979 (D. Del. 1980). As a practical matter, however, the public interest threshold requirement for an award of fees is easily satisfied. Seldom will a nonfrivolous citizen suit against a federal agency fail to at least slightly further the public interest. An award of fees is thus the rule rather than the exception. Whether the public interest is actually and substantially furthered by a citizen suit is, however, a far different question.

63. See supra note 11 and accompanying text.

64. Note, supra note 51 , at 805 . 
policy decisions will be made by a bevy of Platonic Guardians, "65 rather than by elected representatives. And once the precedent for countermajoritarian judicial policymaking is firmly established, its breadth cannot be easily limited.

2. Justiciability Limitations on the Federal Courts. Inherent in citizen suit statutes are many of the same evils that the federal courts attempt to prevent through selfexecuted justiciability limitations. Historically, the courts have adhered to the constitutional mandate that they decide only "cases or controversies" 66 by requiring that the issues presented in a suit be "justiciable." The concept of justiciability embodies two relevant elements. ${ }^{67}$ First, standing to sue requires that the complaining party must have sustained, or be in immediate danger of sustaining, a direct injury as a result of the acts or omissions of the defendant. ${ }^{68}$ Second, the separation of powers and prudential concerns preclude the courts from adjudicating cases that are judicially defined as "political questions."69

Citizen-suit statutes extend justiciability to its farthest limits by relaxing, if not completely removing, the requirement of standing. These statutes greatly expand the number of potential plaintiffs who may initiate an action from those having suffered personal harm - the traditional standard - to any citizen, regardless of whether he has incurred a direct personal injury. Consequently, the courts are presented with general theoretical allegations, rather than the specific, concrete, triable issues that an injured plaintiff normally provides in the pleadings.

The authorization of citizen suits against government agencies also expands traditional notions of justiciability by encouraging the courts to decide cases which, although not labelled as such, fit squarely within the Supreme Court's definition of political questions. ${ }^{70}$ Both the substantive determination in a citizen suit and the fee award decision involve "a lack of judicially discoverable and manageable standards" and "the impossibility of a court's undertaking independent resolution [of such issues] without expressing lack of the respect due coordinate branches of government." ${ }^{\prime 1}$ Citizen-suit legislation requires the courts to entertain challenges to administrative processes and determinations which they routinely refuse to decide under the Supreme Court's established political question criteria for determining when to subject a statute or regulation to minimal judicial scrutiny in deference to the executive and legislative branches. For example, in Sierra

65. L. Hand, The Bill of Rights 73-74 (1958).

66. U.S. CONST. art. III, $\S 2$.

67. Schlesinger v. Reservists Comm. to Stop the War, 418 U.S. 208, 215 (1974),

68. Valley Forge Christian Academy v. Americans United for Separation of Church and State, Inc., 454 U.S. 464, 472 (1982); Ex parte Levitt, 302 U.S. 633, 634 (1937).

69. A political question is one which involves

A textually demonstrable constitutional commitment of the issue to a coordinate political department; or a lack of judicially discoverable and manageable standards for resolving it; or the impossibility of deciding without an initial policy determination of a kind clearly for nonjudicial discretion; or the impossibility of a court's undertaking independent resolution without expressing lack of the respect due coordinate branches of government; or an unusual need for unquestioning adherence to a political decision already made; or the potentiality of embarrassment from multifarious pronouncements by various departments on one question.

Baker v. Carr, 369 U.S. 186, 217 (1962); Powell v. McCormack, 395 U.S. 486, 518-19 (1969).

70. See Baker v. Carr, 369 U.S. 186, 217 (1962).

71. Id. 
Club v. Costle, ${ }^{72}$ one of the original decisions giving rise to Ruckelshaus v. Sierra $C l u b,{ }^{73}$ the court in a voluminous opinion concluded, after reevaluating each step performed by the EPA in promulgating new emissions standards for coal burning power plants, that the EPA had properly construed its congressional mandate. Although the court remarked that it had "on close questions given the agency the benefit of the doubt out of deference for the terrible complexity of the job,"74 the decision clearly revealed that the court had in fact extended no such deference. The many important and difficult-to-balance policy concerns addressed in the EPA's new standards were subjected to judicial scrutiny, thereby seriously sacrificing the values underlying the fundamental premise of our system of government-that policy choices should be made by politically accountable representatives. ${ }^{75}$ Because these challenges often involve policy choices, the courts necessarily decide issues which are resolved more appropriately by a politically sensitive branch of government. ${ }^{76}$

Citizen-suit statutes enlarge the justiciability boundaries of federal courts by disregarding these limitations on judicial power. But in so doing, the statutes also disregard the important purposes behind standing and the political question doctrine. The underlying element of these justiciability concerns is the recognition that by restricting the judicial power to actual disputes in which the parties have real and personal stakes, justiciability not only conserves judicial resources but also prevents the courts from providing "remedies" for every social or economic grievance. ${ }^{77}$ To the extent that citizen-suit statutes and attorney fee shifting legislation encourage adjudication of these controversies, they plainly encourage judicial policymaking.

3. The Courts'Ability to Adjudicate Citizen Complaints. The courts are ill-equipped to decide the types of issues which routinely arise when citizens challenge administrative agency determinations and procedures. To begin with, the extremely overloaded dockets of most federal courts ${ }^{78}$ prevent judges from spending the time necessary to understand an agency determination that probably required months or even years to make. Problems caused by time and other resource constraints are compounded by the lack of judicial expertise in the technical matters involved. ${ }^{79}$

72. 657 F.2d 298 (D.C. Cir. 1981).

73. 103 S. Ct. 3274 (1983).

74. Id. at 410 .

75. It is fundamental that the courts may not "substitute their own pleasure to the . . intentions of the legislature." The Federalist No. 78, at 507 (A. Hamilton) (Mod. Lib. ed. 1937).

76. The Supreme Court has recognized that "judicial intervention is generally unwarranted no matter how unwisely we may think a political branch has acted." Vance v. Bradley, 440 U.S. 93, 96-97 (1978). See also Berger, Commentary- "The Supreme Court As A Legislature": A Dissent, 64 CORNELL L. REV. 988, 993 (1979).

77. The Supreme Court has repeatedly held that "the Constitution does not provide judicial remedies for every social and economic ill." Lindsey v. Normet, 405 U.S. 56, 74 (1972); see also Plyler v. Doe, 457 U.S. 202, 253 (1982) (Berger, C.J., dissenting); Reynolds v. Sims, 377 U.S. 533, 624-25 (1964) (Harlan, J., dissenting).

78. See supra note 35 and accompanying text.

79. It seems obvious that "the legislature is . . . a better fact-finding body than an appellate court" insofar as "the typical legislature will command wider knowledge and keener appreciation of current social and economic conditions than will the typical court." Cox, The Role of Congress In Constitutional Determina- 
Admittedly, federal judges are expected to be generalists capable of educating themselves in concepts and theories foreign to them; nonetheless, the number and complexity of considerations relevant to administrative fact finding and decisionmaking in the fields in which citizen suits are available render these problems and their administrative solutions uniquely inappropriate for judicial reevaluation. ${ }^{80}$

Exacerbating the difficulties inherent in judicial review of an agency determination is the distinctive characteristic of citizen suits-plaintiffs need not assert any personal injury resulting from the challenged determination. Thus, the court must focus not on any discrete and comprehensible relationship between the plaintiff and the defendant, but rather on the long range and far reaching implications of an often unimplemented governmental choice. In short, not only does the court review an agency determination that has often taken years to make, and not only must the court assimilate information that is highly specialized and complex, but it must also do so in a context practically devoid of the particularity and concreteness that a plaintiff who suffers actual loss brings to court. Even one with abundant faith in the federal judiciary should be reluctant to tax its abilities and resources so severely. The burden on the courts is increased by the award of attorney fees which fosters litigation by providing previously unavailable financial incentives for private litigants to challenge administrative actions.

4. Political Accountability. A less obvious reason that the courts are ill-suited as ultimate arbiters of administrative determinations is the lack of political accountability in life-tenured federal judges. The Constitution incorporates norms of selfgovernment which entrust the development, evaluation, and implementation of national public policy to the elected branches of government. ${ }^{81}$ One major benefit of this entrustment is the responsiveness of public policy to electoral influence. Popular elections enable the electorate to insist on desired changes in policy by voting for candidates sympathetic to their views, thereby making officials attentive to voter sentiments between elections. The power to influence public policy increases citizen participation in the electoral process, encourages citizens to educate themselves about policy issues, and enhances the legitimacy of government in the eyes of the people. To the extent public policy is forged in litigation by unelected federal judges with lifetime tenure, these foremost democratic values are thwarted..$^{82}$ Neither history nor policy provides an adequate justification for the impairment of these democratic principles upon which our government is premised.

Rather than the mere administration of a legislative mandate, federal agency rules and procedures, regularly challenged in citizen suits subsidized by attorney fee awards, are precisely those policy issues for which our constitutional system assigns responsibility to the politically accountable branches of government. Challenges to administrative determinations demand solutions far beyond the scope of

\footnotetext{
tions, U. Cin. L. Rev. 199, 209 (1971). This observation is even truer with respect to federal administrative agencies and their presumed regulatory and scientific expertise.

80. See, e.g., Powell v. Pennsylvania, 127 U.S. 678, 685 (1888).

81. U.S. CONST. arts. I \& II.

82. See L. Hand, supra note 65; J. Thayer, John Marshall 106-07 (1901).
} 
the judicial function which has historically been limited to the application of statutory and common law to particular factual situations.

Administrative agencies must frequently balance competing policy objectives. In promulgating rules, regulations, and standards, agencies do not simply implement existing public policy, but rather develop solutions which account for these disparate objectives, based on the agencies' experience and expertise. Illustrative of the many multifaceted issues which require administrative solutions are what levels of sulphur dioxide emissions we are willing to tolerate in the air ${ }^{83}$ and how much of the Alaska continental shelf should be leased or sold to private companies in order to exploit domestic oil and gas resources. ${ }^{84}$ At the risk of redundancy, it is apparent that citizen-suit and attorney fee provisions shift responsibility for these important policy choices from the administrative agencies, which were legislatively created to make such choices, to the courts, which were not. ${ }^{85}$ These provisions thus promote, indeed compel, judicial policymaking.

5. Judicial Discretion. Even if the public is willing to accept the negative results of citizen suits in order to allow litigants to enforce particular statutory schemes, it does not follow that the enormous amount of judicial discretion created by the standardless, open-ended statutes now in force must also be accepted. ${ }^{86}$ Because the courts have been given few statutory guidelines with respect to the circumstances under which parties should be awarded costs, judges encourage or discourage particular types of litigation based on their personal policy predilections. In failing to formulate standards the courts can apply, Congress has forced the courts to "play legislature in [their] 'interpretations' of the statute." 87

The cost shifting provisions of citizen-suit legislation ${ }^{88}$ are typified by section 307(f) of the Clean Air Act. ${ }^{89}$ Congress amended an earlier version of the Clean Air Act to permit courts to award fees and other costs when "appropriate." This amendment instructed the courts to relax the standard for awards of costs from that which was then being applied. The House Committee on Interstate and Foreign Commerce stated: "The Committee did not intend that the court's discretion to award fees under this provision should be restricted to cases in which the party seeking fees was the 'prevailing party.' In fact such an amendment was expressly

83. EPA standards limiting the amount of sulfur dioxide emissions by coal burning power plants were challenged in Sierra Club v. Costle, 657 F.2d 298 (D.C. Cir. 1981), the original case that gave rise to the attorney fees issue in Ruckelshaus v. Sierro Club, 103 S. Ct. 3274 (1983).

84. The Secretary of the Interior's decision to sell outer continental shelf land was at issue in North Slope Borough v. Anders, 642 F.2d 589 (D.C. Cir. 1980).

85. The core of judicial discretion is choice:

To say that a court has discretion in a given area of law is to say that it is not bound to decide the question one way or the other. In this sense, the term suggests that there is no wrong answer to the questions posed-at least there is officially no wrong answer.

Rosenburg, Judicial Discretion of the Trial Court-Viewed from Above, 22 SYRACUSE L. REV. 635, 636-37 (1971) (emphasis in original).

86. "That system of law is best which confides as little as possible to the discretion of the judge . . . ." B. Shientag, The Personality of the Judge 94 (1944) (quoting an old Latin proverb).

87. Alabama Power Co. v. Gorsuch, 672 F.2d 1, 8 (D.C. Cir. 1981) (Wilkey, J., dissenting).

88. See supra notes 5-6 and accompanying text.

89. 42 U.S.C. $\$ 7607$ (f) (Supp. V 1981). 
rejected by the Committee. . .."90 But, even though Congress was explicit that "appropriate" was not to be the equivalent of "prevailing," Congress completely failed to define the term "appropriate."91 Indeed, the term "appropriate," absent further definition and some point of reference, necessitates a policy choice rather than a judicial evaluation. As Professor Charles Black noted, the issue is

$$
\begin{aligned}
& \text { whether the materials available as foundations for judicial judgment contain . . . concepts } \\
& \text { and terms so vague and ambiguous, so intractable to the normal intellectual processes } \\
& \text { of law, that a congressional command to interpret them must be disobeyed on the Article } \\
& \text { III ground that the judiciary has been commanded to perform a non-judicial func- } \\
& \text { tion. . ...92 }
\end{aligned}
$$

The term "appropriate," as used in the cost shifting provisions of the Clean Air Act and similar legislation, is precisely the kind of "vague and ambiguous" concept Professor Black had in mind. The failure of Congress to establish standards to guide the courts forces them to formulate their own standards. The courts not only decide who must bear the costs of litigation, but in making decisions as to costs, also promote particular kinds of challenges to administrative determinations. In creating their own standards and thus influencing the kinds of challenges that come before them, courts engage in public policymaking, which in Professor Black's terminology is unmistakably a "non-judicial function." And the courts have not remedied the vague command of those fee shifting provisions by interpreting the statutes in a manner which fetters judicial discretion. The Supreme Court in Ruckelshaus $v$. Sierra Club ${ }^{93}$ minimally restricted judicial discretion to award fees and other expenses in citizen suits by requiring only that plaintiffs succeed on at least one claim (among the many they have asserted) before they may receive a fee award. ${ }^{94}$ The Court leaves open the prospect that a plaintiff could receive his litigation expenses on the basis of his "success" on a minor part of his case. Even after Ruckelshaus, governmental policy might be vindicated, and the basic agency determination validated, but based on a relatively insignificant procedural deficiency, the government may nevertheless be required to pay the costs of a challenge to its judicially sanctioned action.

The inimical combination of vague language and the absence of either clear legislative guidelines or intent produces a situation in which federal judges have an almost unlimited discretion to award fees according to their own policy proclivities. This discretion thrusts the courts into the forefront of policymaking in fields where fee shifting is available. In this context, Chief Justice Marshall's well-known declaration that it is "the province and duty of the judicial department to say what the law is"95 takes on an entirely new meaning.

90. House Report, supra note 13 , at 1416 .

91. Although the House Committee on Interstate and Foreign Commerce cites National Resource Defense Council, Inc. v. EPA, 484 F.2d 1331, 1338 (1st Cir. 1973), for an interpretation of "appropriate" similar to that intended by the Committee House Report, supra note 13, at 1416, it seems that the citation is intended to support the Committee's rejection of "prevailing" as the sole criterion for fee awards. The Report does not expressly adopt the standards applied in National Resource Defense Council, nor are these standards particularly helpful.

92. C. Black, Decision AcCording to LaW 42-43 (1981).

93. 103 S. Ct. 3274 (1983).

94. Id. at 3281 .

95. Marbury v. Madison, 5 U.S. (1 Cranch) 137, 177 (1803). 


\section{Alternatives}

What are the alternatives to existing citizen-suit statutes and their cost shifting provisions? The first apparent alternative is to return to historical notions of justiciability. This approach would necessitate eliminating citizen suits per se, although a general cause of action would remain for individuals suffering cognizable injury. A return to traditional ideas would relieve the courts from resolving direct personal disputes in which the complaining party has suffered no personal loss or in which the "rights" or "duties" asserted are political rather than legal in nature. Following this course would also entail a return to the American rule which presumes that a sufficient incentive for litigation exists when there is an expectation of success on the merits, while the probability of loss on the merits deters frivolous or weak claims. Adherence to the rule would force potential litigants to assess the value of their particular claims in contradistinction to the present citizen-suit system which requires no individual stake in the outcome and therefore no such assessment. Retaining these traditional concepts would greatly reduce the delay and added expense caused by the unnecessary interference of private litigants and federal judges in the administrative process. More important, the traditional rules would reduce the opportunity for "lawmaking" according to the politically unchecked policy views of a single judge.

Assuming Congress is unwilling to abandon citizen suits, it should revise and improve the present fee shifting provisions by making three primary changes. First, the provisions ought to require clearly that fee shifting be in fact two-way to discourage trivial claims. More precisely, when the government prevails against a private litigant, the government should receive its actual, reasonable litigation expenses including attorney fees incurred in defending the suit. Conversely, when the private litigant prevails he should receive his reasonable litigation expenses. The terms "prevail" or "success" should be explicitly defined to guide the courts in cases where both parties have prevailed to some degree. To accomplish the disincentive purpose of fee shifting, a party should not be able to recover its costs unless it has prevailed on the predominant part of its case; the "prevailing" party should be the litigant who has won more of the case than it has lost. Second, the various provisions authorizing the award of costs in citizen suits should be phrased consistently so that improper distinctions are not drawn from slightly different word usage. Third, Congress should expressly identify the standards that courts are to apply in awarding costs. In determining these standards, Congress should look at the experiences courts have had with various approaches and decide whether these approaches encourage the right kinds and prevent the wrong kinds of litigation. It should be remembered, however, that these revisions, although representing an improvement of the present citizen suit fee shifting scheme, are not preferred over the complete elimination of such statutorily permitted attorney fee awards. The following model statute illustrates the above recommended changes:

In any judicial proceeding under this section, [i.e., the substantive law containing the citizen-suit provision] the court may award costs of litigation (including reasonable attorney 
and expert witness fees) to any party including the federal government upon a finding that the following circumstances are present:

A. The party has substantially prevailed, and

B. The party has sought to effectuate the purposes of this section by:

1. Supplying new and important information;

2. Raising a significant interest that was not considered in a legislative or administrative forum;

3. Demonstrating the failure of governmental departments, agencies, or officials to fulfill nondiscretionary responsibilities delegated to them under this section; or

4. Demonstrating that challenged administrative procedures or determinations were performed in violation of this section.

After Congress revises the cost shifting provisions, it should evaluate the application of the new provisions as soon as there is sufficient information to make a meaningful appraisal. Congress should determine whether the economic and other policy objectives of fee shifting are being satisfactorily achieved. More specifically, does the legislation encourage citizen enforcement of the statutory scheme? Has two-way fee shifting deterred frivolous suits? To what extent have citizen suits impeded the admininstrative process? The point here is that the precise consequences of citizen-suit statutes are unknown, which necessitates an early evaluation of the actual effects of suits authorized by the statutes.

\section{CONCLUSION}

In recent years it seems that political decisionmaking has become a task ingeniously avoided with disturbing frequency by Congress. As a result of this trend, Congress has increasingly abdicated a substantial part of its responsibility to the other branches of government. The shift to the judicial branch means that decisions once made through the political process are now adjudicated. What adjudicative, as opposed to political, decisionmaking means, however, is that decisions are made with a view to the interests of the few parties before the court rather than society as a whole. Adjudicative decisionmaking also means that the decisionmakers are not directly accountable to any constituency. When Congress relinquishes responsibility for fundamental policy choices to the courts, government not only becomes far less susceptible to popular influence, but also far more vulnerable to the personal views of life-tenured federal judges. Awards of attorney fees greatly increase policy-oriented litigation, thus affording unaccountable judges greater opportunity to make decisions more appropriately made by elected branches of government. Equally important, citizen suit fee shifting cannot be justified under the basic economic principles of efficient resource allocation.

Genuine representative government cannot flourish when conventional wisdom grudgingly insists that no government action is either lawful or legitimate until approved by a federal judge. As President Lincoln eloquently warned:

[T] he candid citizen must confess that if the policy of the Government upon vital questions affecting the whole people is to be irrevocably fixed by decisions of the Supreme Court the instant they are made in ordinary litigation between parties in personal actions, the people 
will have ceased to be their own rulers, having to that extent practically resigned their Government into the hands of that eminent tribunal. ${ }^{96}$

From the foregoing analysis, it is plain that the foundation of justification on which citizen-suit fee shifting rests is unpersuasive and unsound. It is one thing for Congress to allow, as it should and must, those substantially and adversely affected by government decisions to challenge them in court. It is quite another thing for Congress deliberately to induce and reward litigious meddlesomeness by those who simply do not like the results of our political and administrative processes (and who could instead try to change the results through these same processes). As the legislative history of citizen-suit fee shifting provisions strikingly reveals, the above economic and structural criticisms of these misguided statutes have not previously been considered by Congress. 